\title{
Toward a Political and Historical Economics Reflections on Capital in the Twenty-First Century
}

\author{
Thomas Piketty
}

\begin{abstract}
I would like to see Capital in the Twenty-First Century as a work of social science rather than a book about history or economics. It seems to me that, where the social sciences ${ }^{1}$ are concerned, too much time is lost on petty quarrels about boundaries and often rather sterile methodological positions. I believe that these oppositions between disciplines can and should be overcome. I could not have hoped for a greater homage to my approach than this group of texts written by specialists from very different horizons, whose work I deeply admire. ${ }^{2}$ Within the framework of such a short article, it is impossible to respond to all of the points raised in this issue of the Annales and to do justice to the richness of these texts. After briefly reiterating my main hypotheses, I would simply like to attempt to clarify a small number of issues and refine certain elements that were undoubtedly insufficiently developed in my book, in particular from the perspective of the multidimensional history of capital and power relations.
\end{abstract}

This article was translated from the French by Angela Krieger and edited by Chloe Morgan and Nicolas Barreyre.

1. This use of "social sciences" is more akin to the expansive definition-common forty years ago in the United States and still prevalent in France-than the much narrower sense that seems to have become dominant in many English-speaking contexts today.-Annales.

2. I am extremely grateful to the Annales for having assembled these texts and to the authors for the attention and time they were willing to devote to my work. 


\section{Capital and the Social Sciences}

First of all, I would like to briefly summarize what I have tried to do in this work and how it fits into the history of the social sciences, where many research traditions and schools of thought intersect. It is above all a book about the history of capital, the distribution of wealth, and the conflicts raised by this unequal distribution. My main objective was to bring together historical sources relating to the evolution of wealth and income in over twenty countries since the eighteenth century, thanks to the combined work of some thirty researchers (notably Anthony Atkinson, Emmanuel Saez, Gilles Postel-Vinay, Jean-Laurent Rosenthal, Facundo Alvaredo, and Gabriel Zucman). The primary ambition of my book was to present this historical material coherently. I began with sources and proposed an analysis of the economic, social, political, and cultural processes that make it possible to account for the evolutions observed in the various countries since the Industrial Revolution. In doing so, I attempted to return the issue of distribution and the inequalities between social classes to the center of economic, social, and political thought.

Nineteenth-century political economy-particularly the works of Thomas Malthus, David Ricardo, and Karl Marx-already placed the issue of distribution at the heart of its analysis. These authors were often motivated by the profound social changes they perceived around them. Malthus was marked by Arthur Young's accounts of poverty in the French countryside on the eve of the Revolution and feared more than anything else that overpopulation would bring about poverty and revolutionary chaos everywhere. Ricardo based his analysis on clear-sighted intuitions about the price of land and the impact of the public debt accumulated by Great Britain following the Napoleonic Wars. Marx accurately observed the profound imbalance between the evolution of profits and salaries in the booming industrial capitalism of the first two-thirds of the nineteenth century. Even though they did not have systematic historical sources for studying such evolutions at their disposal, these authors at least had the merit of asking the right questions. Throughout the twentieth century, economists all too often sought to remove themselves from the social sciences (an illusory temptation, if ever there was one) and to pass over the social and political foundations of economics. Some authors-particularly Simon Kuznets and Anthony Atkinson-nonetheless patiently embarked on the meticulous task of collecting historical data on the distribution of income and wealth. My research directly stems from these studies and has largely consisted of extending the collection of historical data to a broader geographical and temporal scale (an extension that has been greatly facilitated by information technologies, which have made available data inaccessible to previous generations of researchers). ${ }^{3}$ 
In my work, I also attempt to renew a tradition that used to be very prominent within economic and social history, and in particular within the French-language school of history and sociology that from the 1930s to the 1970s generated numerous studies devoted to the history of prices, salaries, income, and wealth in the eighteenth and nineteenth centuries. I am thinking especially of the major works by François Simiand, Ernest Labrousse, and Adeline Daumard. ${ }^{4}$ Unfortunately, this history (sometimes qualified as "serial") died out before the end of the twentieth century-largely for the wrong reasons, it seems to me. ${ }^{5}$ My approach is also inspired by sociological studies on inequalities of cultural capital and disparities in wages, notably those conducted by Pierre Bourdieu and Christian Baudelot (in different but, I think, complementary registers). ${ }^{6}$

Furthermore, in my book I tried to show that it is possible-and, in fact, indispensable - to simultaneously study the evolution of collective representations of social inequality and money in both public debates and political conflicts as well as in literature and cinema. I am convinced that such an analysis of the systems of representations and beliefs about the distribution of income and wealth, however incomplete and preliminary it is within my book, is essential when it comes to understanding the dynamic of inequality. Money and its unequal distribution constitute the supreme social object and cannot be studied from an exclusively economic perspective. In this respect, my work is akin to and feeds off the many studies devoted to perceptions of equality and inequality issuing from the fields of political sociology and intellectual history. ${ }^{7}$

construction of the data assembled in my book are summarized in Thomas Piketty, Capital in the Twenty-First Century, trans. Arthur Goldhammer (Cambridge: Belknap Press, 2014), 16-20.

4. In particular, see: François Simiand, Le salaire, l'évolution sociale et la monnaie. Essai de théorie expérimentale du salaire, introduction et étude globale (Paris: Alcan, 1932); Ernest Labrousse, Esquisse du mouvement des prix et des revenus en France au XVIII siècle (Paris: Dalloz, 1933); Jean Bouvier, François Furet, and Marcel Gillet, Le mouvement du profit en France au XIX ${ }^{e}$ siècle. Matériaux et études (Paris/The Hague: Mouton, 1965); and Adeline Daumard, ed., Les fortunes françaises au XIX' siècle. Enquête sur la répartition et la composition des capitaux privés à Paris, Lyon, Lille, Bordeaux et Toulouse d'après l'enregistrement des déclarations de successions (Paris/The Hague: Mouton, 1973).

5. See Piketty, Capital, 575-77.

6. In particular, see: Pierre Bourdieu and Jean-Claude Passeron, The Inheritors: French Students and their Relation to Culture, trans. Richard Nice (Chicago: University of Chicago Press, 1979); Bourdieu and Passeron, Reproduction in Education, Society and Culture, trans. Richard Nice (London: SAGE, 1990); and Christian Baudelot and Anne Lebeaupin, "Les salaires de 1950 à 1975 dans l'industrie, le commerce et les services" (Paris: INSEE, 1979).

7. In different registers, see, for example: Michèle Lamont, Money, Morals and Manners: The Culture of the French and American Upper-Middle Class (Chicago: University of Chicago Press, 1992); Jens Beckert, Inherited Wealth, trans. Thomas Dunlap (Princeton: Princeton University Press, 2004; repr. 2008); Pierre Rosanvallon, The Society of Equals, trans. Arthur Goldhammer (Cambridge: Harvard University Press, 2013); and Jules Naudet, Entrer dans l'élite. Parcours de réussite en France, aux États-Unis et en Inde (Paris: PuF, 2012). 
In fact, the main conclusion of this work is that "one should be wary of any economic determinism in regard to inequalities of wealth and income. The history of the distribution of wealth has always been deeply political, and it cannot be reduced to purely economic mechanisms. ... The history of inequality is shaped by the way economic, social, and political actors view what is just and what is not, as well as by the relative powers of those actors and the collective choices that result. It is the joint product of all relative actors combined." 8

The central role of politics and the changing representations of the economy is particularly evident when studying the evolution of the distribution of income and wealth throughout the twentieth century. The reduction of inequality observed in Western countries between the 1900s-1910s and the 1950s-1960s is largely explained by the wars and revolutions that marked this period, as well as by the new social and institutional compromise that emerged following such upheaval. Similarly, the rise in inequality observed since the 1970 s and 1980 s owes much to the political and institutional reversal of recent decades, notably in fiscal and financial matters. I also tried to show that the belief systems surrounding the distribution of income and wealth as a function of the economy and society play a central role in our understanding of the structure of inequality in the eighteenth and nineteenth centuries and, in fact, within all societies. Each country has its own intimate history with inequality, and I tried, for example, to show that national identities and the representations each country has of its own economic and historical trajectory play an important role in the complex interaction between the dynamics of inequality and the evolution of perceptions and institutions. ${ }^{9}$

This results in a wide variety of political and institutional forms that are often only briefly touched upon within the framework of my book but which play a fundamental role in the dynamics of inequality and warrant further study in terms of both their intellectual and political genesis and how they were established in practice. I particularly insisted upon the role of educational institutions and the way in which they can sometimes reduce or, on the contrary, amplify inequalities, ${ }^{10}$ as well as on the role of fiscal institutions, particularly the difficult and fragile emergence of the progressive tax on income, inheritance, and wealth. ${ }^{11}$ A large number of other public and socio-political institutions also play an important role. These include: the development of the social state in the broad sense ${ }^{12} ;$ monetary regimes, central banks, and inflation; labor legislation, the minimum wage, and collective bargaining; nationalization, expropriation, and privatization; slavery and forced

\section{Piketty, Capital, 20.}

9. In particular, see the case of the conservative revolutions that took place in America and Britain, notably analyzed in ibid., chaps. 2 and 14 .

10. Ibid., chaps. 8 and 13 .

11. Ibid., chaps. 14 and 15.

12. Ibid., chap. 13. On the construction of the social state and the role of social spending in the reduction of inequality and the development process, see Peter H. Lindert, Growing Public: Social Spending and Economic Growth Since the Eighteenth Century (New York: Cambridge University Press, 2004). 
labor; corporate governance and the rights of salaried workers; the regulation of rent and other forms of control over prices and usurious interest rates; financial deregulation and the flow of capital; commercial and migratory policies; inheritance regulations and property regimes; demographic and familial policies; and so on. I will return to some of these aspects later on.

\section{A Multidimensional History of Capital and Power Relations}

Let us now turn more precisely to the notion of capital that I develop in my book. I have tried to write a multidimensional history of capital and of the relations of ownership and domination that accompany different forms of possessions and assets. I attempt to show how, at each stage, the different metamorphoses of capital lead to new social and institutional compromises that enable the relationships between social groups and the relations of production to be regulated. It should be clarified from the outset that this is ultimately just an introduction to such a multidimensional history, since numerous aspects are only outlined in my book.

Unidimensional economic models for the accumulation of capital, abstract concepts, and equations (such as the inequality $r>g$, which I think makes it possible to better grasp certain invariables within these metamorphoses) also play a certain part in my analysis. However, this is a relatively modest and limited role-one that, in my view, corresponds to what theoretical modeling and equations can bring to research in the social sciences. This kind of extreme simplification of the real occasionally isolates some interesting logical relationships between two given abstract concepts. It can be useful, but only provided that one does not overestimate the scope of this type of abstract operation, nor lose sight of the fact that all the concepts in question are ultimately nothing more than socially and historically determined constructions. Theoretical models form a sort of language, one that is only useful when they are solicited in conjunction with other forms of expression that participate in the same deliberative and conflictual process.

As I note as early as the first chapter, where I define the main notions explored in my book, "The boundary between what private individuals can and cannot own has evolved considerably over time and around the world, as the extreme case of slavery indicates. The same is true of property in the atmosphere, the sea, the mountains, historical monuments, and knowledge. Certain private interests would like to own these things, and sometimes they justify this desire on the grounds of efficiency rather than mere self-interest. But there is no guarantee that this desire coincides with the general interest. Capital is not an immutable concept: it reflects the state of development and prevailing social relations of each society." 13

The fact that the forms assumed by the possession of capital and the nature of ownership rights are historically determined is clearly demonstrated in my analysis of the importance of slavery and slave capital in forms of wealth in the southern 
United States before 1865, without a doubt the most extreme example of relations of ownership and domination by owners over others. ${ }^{14}$ It is equally evident when I examine the relatively low stock-market capitalization of German companies compared to their Anglo-American counterparts, ${ }^{15}$ a phenomenon undoubtedly linked to the fact that German shareholders are less omnipotent than shareholders elsewhere and must to some degree share power with employees, regional governments, and other stakeholders (though this evidently does not prevent a certain level of productive efficiency). This clearly demonstrates that the market value and the social value of capital are two quite distinct things.

More generally, I tried to show the multitude of forms assumed by capital and its market valuations throughout history, from agricultural land to real estate and professional, financial, and immaterial modern capital. Each type of asset has its own economic and political history and involves relations of power and specific social compromises. Thus, large-scale movements in real-estate prices and rent levels, whether upward or downward, have played a decisive role in the evolution of real-estate capitalization over the course of the last few decades, just as they did during the first half of the twentieth century. ${ }^{16}$ These movements are themselves the result of a complex group of institutional, social, and technological forces, including the contrasting evolution of rent control policies and other rules governing relations between landlords and tenants; the changes in economic geography and residential segregation; and the varied rhythms of technical change in construction and transportation compared to other sectors. There are, however, other examples. On several occasions in the book, I examine the importance of petroleum capital and its distribution worldwide, the accompanying relations of domination and military protection (notably in the Middle East), and its impact on the sometimes unusual financial investment strategies employed by corresponding sovereign wealth funds. ${ }^{17}$

The hypertrophy of gross asset positions between countries, which has been one of the main characteristics of the process of financial deregulation over the last few decades, is another recurring theme in the book. ${ }^{18} \mathrm{I}$ also analyze the extremely high levels of foreign assets held by Great Britain and France during the late nineteenth and early twentieth centuries, a time when both countries possessed an important share of the rest of the world. The very substantial rents, dividends, and interest that this brought in-the equivalent, in Belle Époque France, of the entire production of the country's industrial east-enabled them to finance a permanent commercial deficit while continuing to acquire a growing share of the rest of the world (which did not fail to stimulate tensions between colonial powers). I compare these levels with those reached in the early twenty-first century by the net asset positions of Germany, Japan, China, and the oil-rich countries, which to 
date remain markedly lower but are rising very rapidly (prompting, in countries such as France, fears of one day becoming the owned rather than the power that owns).

On a number of occasions, I insist on the fact that relations of international ownership always come charged with multiple tensions and are light-years away from the calm theoretical models of economists, regulated by natural harmony and mutually profitable exchange. In general, relations of ownership are always complex and difficult to organize calmly within the framework of a political community. It is never simple, for example, to pay rent to one's landlord and amicably agree on the institutional framework of the relationship and the perpetuation of the situation-hence the multiple systems in place for controlling rent, lengthening leases, and taxing inheritance. But when an entire country is paying rents and dividends to another country, the situation can become even more tense and the means of regulating this relationship are generally less peaceful. This often results in relations based on military domination by those in the position of ownership. Or else, the country in the position of being owned goes through unending political cycles in which phases of triumphant ultraliberalism and authoritarianism alternate with brief periods of chaotic expropriation-a phenomenon that has consistently undermined the development of numerous countries, particularly in Latin America and Africa. The peaceful regulation of social inequality and relations of ownership represents one of the most important stakes in the construction of a rule of law and legitimate public power, and involves developing norms of justice and complex institutional structures. When inequality and ownership are largely external to a given political community, this construction can find itself lastingly impaired. Economic rationality in fact tolerates the perpetuation of inequality rather well, and in no way leads to democratic rationality.

Public capital also plays a central role in my analysis of the history of capital. ${ }^{19}$ This can be positive or negative, depending in particular on political and ideological cycles of public investment and nationalization or, on the contrary, public deficit and privatization. In the former case, public capital diminishes the hold of private capital over national capital and society; in the latter, it reinforces this hold by adding government bonds to private assets as an additional element of ownership and domination. I also analyze the importance of inflation when it comes to the dynamic of public debt and, more generally, the role of monetary creation and the different operations involving the redistribution of national capital performed by central banks. ${ }^{20}$ I stress the diversity of national experiences and trajectories when it comes to public debt, in particular by contrasting the cases of France and Great Britain in the eighteenth and nineteenth centuries and then Germany in the twentieth century-a development that is not without interest in the current European context, as countries that never reimbursed the public debts they incurred during the twentieth century (notably France and Germany) explain to countries in southern Europe that they must pay more in interest to bondholders than they invest in 
their school system for decades to come (just as the British did in the nineteenth century). Phases in which evolutions converge can also be observed. For example, public capital represented a significant part of national capital in most European countries during the postwar period (between a quarter and a third) and has fallen to very low levels over the course of the last few decades (and even to negative levels, as in Italy). In many instances, these movements of public debt and privatization favored particularly rapid private enrichment, not only within developed countries, as one would expect, but also and above all in post-Communist countries, beginning with Russia and China.

Throughout the book, I have tried to show that the history of capital is multidimensional and that each of these categories of assets and possessions involves a wide variety of institutional mechanisms and compromises. Ownership assumes multiple forms that are historically and socially determined and which trace just as many social relationships. The fact that it is also possible to add up all these forms of wealth-by using, for example, the current market prices for the different assets (supposing that they are well defined, which is not always evident) - in order to calculate the total monetary value of the stock of capital in no way changes this manifold reality. This abstract operation can certainly be useful; it enables us, for example, to discern that despite multiple metamorphoses in the forms that capital takes, in the early twenty-first century this total market valuation (expressed in years of national income) appears to have returned to a level nearing that observed in the patrimonial societies that prospered from the eighteenth and nineteenth centuries up until the Belle Époque. This provides a language that enables the overall scale of market valuations to be compared in societies that are otherwise very different from one another. However, such an overarching measurement does not make it possible to take into account the multiplicity of relations of ownership and production that develop in these different societies.

The approach that I develop in my book is in fact only an introduction to a multidimensional history of capital and forms of possession, since it neglects a large number of essential aspects and touches on others only briefly. For instance, as Nicolas Barreyre very astutely points out, the geographical and spatial dimensions of capital would repay further examination. ${ }^{21}$ While much attention is paid to possessions outside of France and Great Britain, nothing has been said about possessions within countries-for instance, between the northeastern United States and the rest of the country. More generally, Alessandro Stanziani observes how useful it would be to vary the scale of analysis, from the national level to the imperial level up to the world-economy. ${ }^{22}$ In particular, this would make it possible to examine much more directly than I do in my book the impact of colonization on development and the overall effects of domestic and international inequality on the construction of a legitimate public power. Katia Béguin emphasizes the importance 
of the creation of new assets by the early modern state, not only by issuing bonds but also by selling charges and offices. ${ }^{23}$ This public extension of private property appears to have been a major catalyst for the concentration of wealth. Éric Monnet rightly observes that the history of monetary regimes and operations involving the redistribution of national capital performed by central banks and public authorities is for the most part yet to be written. ${ }^{24} \mathrm{He}$ also presents interesting data suggesting that the share of the monetary mass (coins, banknotes, and current accounts) in private capital in France and Great Britain (around 10 percent in 1900-1910, as in 2000-2010) reached its peak around 1950 (over 20 percent in Britain and over 40 percent in France), a fact which should no doubt be considered alongside the mid-century collapse of the system of financial intermediation. All these different aspects of capital—and indeed many others—-merit further examination.

\section{Financial Capital and Cultural Capital: Reconciling Marx and Bourdieu}

I would now like to turn to another essential aspect of the multidimensionality of capital. Throughout my book, I distinguish between two social hierarchies: that of wealth and that of labor income. Both hierarchies are, of course, closely related, and in some societies they largely coincide. However, they are never exactly the same, since the 50 percent at the bottom (sometimes designated within the framework of my book as the "lower class" for clarity and to allow for comparisons across time and space), the 40 percent in the middle (the "middle class"), and the 10 percent at the top (the "upper class," within which I frequently distinguish the 1 percent at the very top, or the "dominant class") do not correspond to precisely the same social groups depending on which of the two hierarchies is being examined. Sometimes they are even completely different, as in traditional patrimonial societies where those in possession of large fortunes are unembarrassed about not working and dominate most of society.

Above all, in each society these two hierarchies mobilize quite distinct mechanisms of domination and inequality production that are potentially complementary as well as cumulative. The hierarchy of wealth is determined by multiple processes that contribute to the accumulation of real-estate, professional, and financial capital, already mentioned above. These include placement and investment strategies, inheritance regulations and property regimes, the functioning of financial and real-estate markets, and so on. The hierarchy of labor income notably depends on rules and institutions contributing to the formation of salaries and different work statuses and contracts; the inequality of skills and relations; the

23. Katia Béguin, "From the Present to the Past: The Historical Dynamics of Wealth in Early Modern Europe," Annales HSS (English Edition) 70, no. 1 (2015): 87-97.

24. Éric Monnet, "Money and Capital: The Contributions of Capital in the Twenty-First Century to Monetary History and Theory," Annales HSS (English Edition) 70, no. 1 (2015): 33-44. 
functioning of the education system; and, more generally, the hierarchy of cultural capital. Both hierarchies - that of financial capital and that of cultural capital, to put it simply_also correspond to different systems of discourse and justification. Traditional patrimonial inequality generally does not seek to base its domination in merit or in cultural superiority, at least not primarily. On the contrary, modern inequality aims to justify itself through an ideology resting on merit, productivity, and virtue. As Giacomo Todeschini notes, ${ }^{25}$ this system of justification, based on stigmatizing the "undeserving poor" and what I call "meritocratic extremism,"26 has ancient origins. It can be traced back to the Middle Ages and perhaps even to the end of slavery, forced labor, and the pure and simple ownership of the poor classes by the rich classes (when the poor person becomes a subject and not just an object, he or she must be possessed by other means). However, it reaches its maximum extension in the modern era. ${ }^{27}$

Are we witnessing in the twenty-first century the emergence of a new inegalitarian model that combines a return to the patrimonial and capitalistic inequalities of the past with extreme forms of domination based on cultural capital, symbolic capital, and blaming the victims of the system? That is in any case one of the hypotheses I formulate in my book. In particular, I note the gaping hypocrisy of contemporary meritocratic discourses. For example, the average income of parents of students at Harvard University currently corresponds to that of the wealthiest 2 percent of Americans. In France, the most elitist educational programs recruit their students from social pools that are barely any larger, and three or four times more public resources are invested in them than in programs open to ordinary students, without anyone batting an eyelid. ${ }^{28}$ Besides this privileged access to cultural and symbolic capital, over the last few decades these ruling groups have increased their capacity to award themselves extravagant pay packages and bonuses-with weakened unions and fiscal policies incapable of providing effective resistance. ${ }^{29}$

25. Giacomo Todeschini, "Servitude and Work at the Dawn of the Early Modern Era: The Devaluation of Salaried Workers and the 'Undeserving Poor," Annales HSS (English Edition) 70, no. 1 (2015): 77-85.

26. Piketty, Capital, chaps. 11, 12, and 13.

27. A particularly distinct expression of this can be found in an astounding declaration by Émile Boutmy, who created the École libre des sciences politiques (commonly known as Sciences Po) in 1872 and set out its mission thus: "Obliged to submit to the rule of the majority, the classes that call themselves the upper classes can preserve their political hegemony only by invoking the rights of the most capable. As traditional upperclass prerogatives crumble, the wave of democracy will encounter a second rampart, built on eminently useful talents, superiority that commands prestige and abilities of which society cannot sanely deprive itself." Cited in Piketty, Capital, 487.

28. Ibid., 485-86. Contrary to what Laurent Thévenot seems to indicate in "You Said 'Capital'? Extending the Notion of Capital, Interrogating Inequality and Dominant Powers," Annales HSS (English Edition) 70, no. 1 (2015): 65-76, I do not believe in the idea of equal opportunities, which is frequently a decoy enabling elite groups to sidestep the idea of equal conditions. I was no doubt insufficiently clear on this topic in my book, hence certain misunderstandings.

130 29. See Piketty, Capital, chaps. 8 and 14, especially pp. 508-12. 
This combination of the effects of both financial capital and cultural capital appears to constitute something new on this scale-particularly in comparison with the postwar period when patrimonial inequality played a lesser role following the military, political, and social upheaval of the years between 1914 and 1945 . As Alexis Spire perceptively remarks, ${ }^{30}$ it was precisely during this time, in the 1960s, that Pierre Bourdieu developed his analysis of forms of domination based on cultural and symbolic capital. These concepts have clearly lost none of their relevance in the early twenty-first century-in fact quite the contrary. It is simply that now they are combined with the return of real-estate and financial capital to a level comparable to that observed in the late nineteenth and early twentieth century. To understand the relationship between production and power in the twenty-first century, it is necessary, it seems to me, to combine Marx's observations with those of Bourdieu in order to develop a real political and historical economics of capital and inequality between social classes.

\section{The Regulation of Capital and Institutional Change}

One of the main weaknesses of my book is undoubtedly that I did not analyze the social and political conditions of institutional change in great enough depth. As Jean-Yves Grenier observes, ${ }^{31}$ changes in social norms often appear exogenous and exterior to my analysis. While I have tried to show that changes in representations and belief systems involve both the short and the long term, my analysis would without a doubt benefit from being pursued further.

In particular, I insisted upon the role of violent political shocks (wars, revolutions, and economic crises) as well as the role of longer learning curves and the cross effects of national identities when it comes to perceptions of inequalities and the economy. In the early 1920 s, one of the most right-wing Chambers of Deputies in the history of the French Republic, the "National Bloc," voted the most heavily progressive tax on the rich (with rates reaching 60 percent for the highest incomes), even though these very same political groups had stubbornly refused to adopt an income tax with a top rate of 2 percent before the summer of 1914 . The ideology whereby France-a country of small landowners rendered egalitarian through the Revolution-had no need for a progressive and spoliating tax (contrary to the aristocratic and inegalitarian Britain) played an important role in this refusal, or at least in the intellectual system that made it possible to justify it. Yet inheritance data unambiguously demonstrates that the concentration of capital had reached extreme levels in the France of 1914, not so different from those observed at the same time in Britain or even in the France of 1789 . While the nature of capital had completely changed (land-based fortunes had become real-estate, manufacturing, financial, and international fortunes), the degree of concentration was scarcely different from

30. Alexis Spire, "Capital, Social Reproduction, and the Rise of Inequality," Annales HSS (English Edition) 70, no. 1 (2015): 57-64.

31. Jean-Yves Grenier, "The Dynamics of Capitalism and Inequality," Annales HSS

(English Edition) 70, no. 1 (2015): 7-20. 
what it had been on the eve of the Revolution, firm proof that formal equality before property laws and the market is not enough to lead to equality itself. The French republican elite did not accept, for better or for worse, to completely change its point of view on fiscal progressivity in the early 1920 s simply because of the human and financial impact of the war: the Bolshevik Revolution and social movements had also completely transformed the political and intellectual landscape.

In a different way, I tried to show that the neo-conservative revolutions of the 1980s were fed not only by the financial crises of the 1970s and the end of the exceptional growth that had followed the war, but also and perhaps above all by certain countries' fear of losing their leading position-or at least the fear that those who had been defeated during the war would catch up. This fear was especially pronounced in the United States and the United Kingdom, and Ronald Reagan and Margaret Thatcher knew how to use it to announce a return to pure capitalism, freed from elements of the mollifying social and fiscal state imposed by interventionists at the end of the Great Depression and the Second World War.

Nicolas Delalande is quite right to remark that the role of long-term, underground movements in these changes should have been more strongly emphasized. ${ }^{32}$ For example, the role of the ideological debates about progressive taxation that took place in the late nineteenth and early twentieth century should not be underestimated, for in many respects they laid the groundwork for later developments. It nonetheless seems to me that without wars, revolutions, and social movements, the political and economic elites in both France and other countries would have continued to deploy their persuasive skills and their influence over the media in order to oppose any substantial move toward progressivity. Nor would it be outrageous to consider that the inequality and extreme social tensions that characterized European societies in the twentieth century could have contributed to the rise of nationalism and even the war itself, which certainly should not be considered exogenous to the socio-economic dynamic of the accumulation and distribution of capital during the previous decades.

Given the essential role played by financial crises, revolutions, and social movements in the history of inequality over past centuries, it would be surprising if these elements did not exert the same influence in the future. The advent of the modern social and fiscal state, which made it possible to develop a system of fundamental social rights that profoundly altered the logic of the capitalist system during the twentieth century, was not the product of a peaceful electoral process. In my book, I did not seek to study the forms that social movements and political reversals will assume in the future, but I have proceeded as if they will play an essential role. I also hope that the democratization of economic knowledge can contribute to the overall process of the democratization of the economy and society. Spire remarks that the project for economic and fiscal democracy that I support cannot be fully achieved without a change in the system of political representation itself, ${ }^{33}$ and I fully subscribe to this idea. Democratic institutions must be continually 
reinvented. For example, within the framework of current European institutions, it is strictly impossible to put in place policies for fiscal justice at a European level, for the simple reason that fiscal decisions are taken according to the rule of unanimity. This is why it is essential to debate the concrete organization of democracy on both the local and the European level. ${ }^{34}$

Another important limitation of the book relates to the fact that I have not analyzed in sufficient depth the possible ways that forms of ownership themselves might evolve. I insisted above all upon the social state and its system of rights as well as on the progressive tax on income and capital. It should be noted that, correctly applied, the progressive tax on capital would enable capitalism and private property to be surpassed in a relatively profound way, since it would transform the latter into a temporary rather than a permanent reality-particularly when it comes to the most sizeable possessions, which could be taxed at very significant rates (for example, 5 or 10 percent each year, perhaps even more according to the reproduction rates observed and the desired social objective). This tax is in many ways the equivalent of a permanent agrarian reform. Furthermore, the financial transparency that would accompany a true progressive tax on capital would contribute in a key way to a democratic reappropriation of capitalism. Finally, I have not sufficiently studied the way in which new forms of ownership and participatory governance lying between private property (which would itself be democratized, thanks to the increased participation of salaried workers in the wielding of economic power) and public property (which must continue to play a role in numerous sectors-not easy when public debt exceeds meager public assets) could be developed in the future, for example, in education, healthcare, and even the media. ${ }^{35}$

The final chapter of my book concludes with the following statement: "Without real accounting and financial transparency and sharing of information, there can be no economic democracy. Conversely, without a real right to intervene in corporate decision-making (including seats for workers on the company's board of directors), transparency is of little use. Information must support democratic institutions; it is not an end in itself. If democracy is someday to regain control of capitalism, it must start by recognizing that the concrete institutions in which democracy and capitalism are embodied need to be reinvented again and again." 36 The fact that I did not explore these new forms more thoroughly in the chapters that precede this statement is undoubtedly the main reason why my book is at best simply an introduction to the study of capital in the twenty-first century.

\section{Thomas Piketty EHESS and École d'économie de Paris}

34. Piketty, Capital, 558-62.

35. On this topic, see Julia Cagé, Sauver les médias. Capitalisme, financement participatif et démocratie (Paris: Éd. du Seuil, 2015).

36. Piketty, Capital, 570. 